ANKAD E-ISSN:2587-0491

\author{
Araştırma Makalesi/Research Article
}

\title{
Libya Matematik Ders Kitaplarının Analizi: İlköğretim Yedinci Sınıftan Dokuzuncu Sinıfa
}

\section{Widad Masaud Omar ALGHIES iD 1 Lütfi İNCíKABi iD 2}

\footnotetext{
${ }^{1}$ Kastamonu Üniversitesi Fen Bilimleri Enstitüsü, Yüksek Lisans Öğrencisi, e-mail: muhammedtalip89@ gmail.com

${ }^{2}$ Prof. Dr., Kastamonu Üniversitesi Eğitim Fakültesi, Matematik ve Fen Bilimleri Eğitimi ABD,

e-mail: lutfiincikabi@gmail.com
}

\begin{abstract}
Anahtar Kelimeler
Matematik, Ders Kitabı, Libyada Matematik

\section{Keywords}

Mathematics, textbook, mathematics in Libya

\section{Sorumlu yazar/Corresponding Author}

Widad Masaud Omar Alghies, Kastamonu Üniversitesi Fen Bilimleri Enstitüsü, Yüksek Lisans Öğrencisi e-mail: muhammedtalip89@gmail.com
\end{abstract}

Geliş/Received: 24.06.2020

Kabul/Accepted: 28.07 .2020

\section{Öz}

\begin{abstract}
$\mathrm{Bu}$ araştırma, Libya'da 7., 8. ve 9. Sinıfta okutulan matematik ders kitapları ile mevcut ders müfredatı arasındaki ilişkiyi ortaya koymayı amaç edinmektedir. Bu bağlamda bu çalışma, Libya'da kullanılmakta olan ortaokul matematik ders kitaplarında matematiksel konuların nasıl kavramsallaştırılıp ele alındığına dair ayrıntılı bir resim sağlamak için matematik konularının içeriklerini, sunumunu ve yer verilen soruları analiz etmeyi amaçlamıştır. Çalışma sonucunda matematik ders kitaplarının içeriği, ele alınan konular, konuların sıralanışı ve konuların kitaptaki oranı (sayfa sayısı) ve matematik programında ayrılan ders süresi ile ilişkisi ortaya konulmuştur. Çalışma sonucunda elde edilen bulgulardan ders kitabının program ile uyumlu olduğu sonucuna varılmıştır.
\end{abstract}

\section{Analysis of Libya Mathematics Course Books: Seventh Grade to Nine Grade}

\begin{abstract}
This study, it is aimed to reveal the relationship between the current course curriculum of the mathematics textbook taught in Libya in 7.8 and 9th grade. In this context, this study aimed to analyze the content, presentation and the questions of the mathematics topics in order to provide a detailed picture of how mathematical issues are conceptualized and handled in secondary school mathematics textbooks used in Libya. As a result of the study, the content of the mathematics textbooks, the topics covered, the order of the topics and the size of the topics in the book (the number of pages) and the relationship between the duration of the mathematics program were revealed. From the findings obtained as a result of the study, it was concluded that the textbook is compatible with the program.
\end{abstract}

\section{Önerilen Atıf / Suggested Citation:}

Alghies, W.M.O. \& İncikabi, L. (2020). Libya Matematik Ders Kitaplarının Analizi: İlköğretim Yedinci Sınıftan Dokuzuncu Sınıfa, Anadolu Kültürel Araştırmalar Dergisi, 4(3),295-314 


\section{1-GÍRİș}

Libya Eğitim sistemleri içinde 7-8 ve 9. Sınıf ortaöğretim olarak tanımlanmaktadır. Eğitim kademesinin başlangıcından sonraki en önemli aşama olan ortaöğretim sisteminde öğrencilerin istendik davranışlarla donanmış bireyler olarak yetiştirilmesi uygulanan eğitim programlarına bağlıdır. Eğitim programı, eğitimde amaçların gerçekleştirilmesinde temel araç olarak gösterilebilir. Öğrencide istenen davranış değişikliklerini oluşturmak, öğretim sırasında dikkatini toplamak, ilgisini artırmak ve devam ettirmek amacıyla çeşitli eğitim araçlarının kullanıldığını görmekteyiz. Bu eğitim araçlarından en önemlisi “ders kitapları"dır. Kitap, sınıfta öğretmen ve yazı tahtasından sonra en sık başvurulan bir araçtır. Hatta birçok durumlarda yaygın olarak kullanılan tek öğretim materyalidir (Kolaç, 2003).

Eğitim araçları arasında özel bir yere sahip olan ders kitaplarının uygun nitelikte olması uygulama ve teorik kısmındaki farkı aza indireceği düşünülmektedir Ders kitaplarının esas belirleyici özelliklerinin başında onların öğrenciler için düzenlenmiş olmaları daha sonra ise ayrıntılı bilgi verme, bilgiler arasındaki ilişkileri açıklama, öğrenciye bildiklerini tekrar ettirme, pekiştirme gibi üstün özelliklere sahip olmaları gelir.

Matematik derslerindeki başarısızlığın nedenleri arasında; kitaplardaki ifadelerin karmaşık ve anlaşılmaz oluşu, verilen örneklerin günlük yaşamla yeterince ilişkilendirilememesi gibi faktörler bulunmaktadır. Diğer ders kitaplarında olduğu gibi, matematik ders kitaplarının hazırlanmasında da dikkate alınması gereken pek çok faktör vardır (Göze, 1999).

Ders kitabının öğrenci için sağladığı faydalar arasında şunlar sayılabilir (Duman ve ark., 2001):

- Ders kitabı, öğretmenin sözlü dersini tamamlar.

- Ders kitabı, sözlü öğretimin boşlukların, eksikliklerini giderir.

- Bilgiler arasındaki bağlantısızlıkları ortadan kaldırır.

- Öğrenilen bilgileri tekrar gözden geçirmeyi mümkün k1lar.

- Ders kitabından çalışılırken öğrenci, daha aktif düşünen ve sorumluluk hisseden bir yapı içindedir.

- Öğrenciyi farklı soru tipleri, sorularla ilgili farklı çözüm yolları ve konu anlatımında ileriye sürülen farklı yaklaşımlarla yüz yüze getirir.

- Öğretimi sıkıcılıktan kurtarır, ilginin devamını sağlar.

- Ders kitabı öğrencinin derse önceden hazırlanmasını sağlar.

Ders kitaplarının hazırlanmasında dikkat edilmesi gereken en önemli husus, dersin öğretim programının dikkate alınmasıdır. Seçilen yöntemler ve teknikler, hedef ve davranışların gerçekleştirilmesinde önemli bir unsurdur.

Öğrenmede; işitme ve görme önemli olmakla beraber, yaparak öğrenme daha yararlı ve sürekli sonuçlar sağlar. Programdaki işleniş örnekleri, günlük hayatla bağlantılı ve öğrenci katılımını sağlayacak nitelikte düzenlenmelidir.

İlköğretim programlarında 2015 yılından itibaren yapılan değişikliklerle birlikte ilköğretimde etkinlik temelli, öğrenci merkezli bir öğretim benimsenmiştir (Libya Eğitim Bakanlığı, 2015). Bu programlarda, öğrencinin yaparak yaşayarak öğrenmesi ve öğretmenin bu öğrenme sürecine rehberlik etmesi vurgulanmaktadır. İlköğretim matematik programında, matematiğin pek çok alanda kullanıldığı ve günlük hayatta matematikle ilgili problemlerle sıkça karşılaşıldığ belirtilmekte ve matematik bilgisinin gerçek hayatla ve diğer disiplinlerle ilişkilendirilmesinin önemi üzerinde durulmaktadır.

Öğrencilerin günlük hayatın içindeki matematiği görmelerinin ve matematiğin diğer dersler için de gerekli olduğunu anlamalarının, matematiği daha anlamlı şekilde öğrenmelerini sağlayacağı 
da açıklanmaktadır (Libya Eğitim Bakanlığı, 2015). Programda, matematiğin fen ve teknoloji, sosyal bilgiler ve Türkçe dersleriyle ortak becerilerinin olduğu ve bu becerilerin kazanılması istenen hedefler içerisinde yer aldığı ifade edilmektedir (Libya Eğitim Bakanlığı, 2015).

Matematik, insanlığın büyük başarılarından biridir (Mckenzie, 2001). İnsanın topluma tam olarak katılabilmesi için temel matematiğini bilmeleri gerekir. Sayısalcılık, bunları sadece fırsat değil, bankacılık ve alışveriş gibi günlük görevlerdeki yetkinlikten de mahrum etmektedir. Matematiksel olarak mantıklı olamayan vatandaşlar, insan çabalarının tüm alanlarından kopar (Kilpatrick ve diğerleri, 2001). Matematik, tümdengelimli akıl yürütme gücünü kullanan mükemmel bir gelişmişlik ve güzelliğin entelektüel bir başarısıdır (Muller \& Maher, 2009). Deductive reasoning (mantıksal süreç) mantıksal bir süreçtir ve sonuçta, bir sonucun genellikle doğru olduğu varsayılan çoklu yapıların uyumluluğuna dayanır. Öğrencilerin bugün öğrenecekleri matematik, ana-baba ve dedesinin öğrenmesi gereken matematikle aynı değildir (Bauer, 2013). Günümüz öğrencileri yetişkin olduğunda, okul matematiğinin tahmin etmeye çalışması gereken yeni matematik yeterliliği talebiyle karşı karşıya kalacaklar. Öğrencilerin kullandığı matematik ders kitabı, matematikteki mantıkların nasıl kullanılacağını öğrenmek için, tümdengelimli akıl yürütmeyi açıklama gibi öğrencilerin ihtiyaçlarını öngörmeye çalışan bir girişimde her yönü ele almalıdır (Muller \& Maher, 2009).

Öğretim programına'a göre, matematiğin dört bilişsel seviyesi vardır: Bilgi, Süreç Prosedürleri, Kompleks Prosedürler ve Problem çözme. Bu çalışmada Libya matematiği için yedi, sekiz ve dokuz sinıflı ders kitaplarını NAEP (National Assessment of Educational Progress) kriterleri çerçevesinde analiz ederek matematik ders kitabının öğrencilerin bilişsel seviyelerine uygun olup olmadığını belirlemektir.

Ders kitaplarını analiz edebilmek için, Libya 7-8-9. sınıf matematik ders kitapları iki teorik çerçeve kullandık. Kullanılan teorik çerçeveler Kilpatrick ve arkadaşlarının (2001) beş matematik yeterliliği ve Marton ve arkadaşlarının (2004) değişkenlik teorisidir. İki yaklaşım ele alınarak ortak bir çerçeve geliştirilecek ve analiz bu iki yaklaşımın sentezlenmesi şeklinde olacaktır.

Öğrencilerin matematiği doğru anlama ve yorumlama konusunda ders kitaplarının önemi tartışmasızdır. Öğrencilerin daha iyi anlaması ya da anlayamamasında önemli rolü olan ders kitaplarının öğrencilerin daha yüksek matematiksel akıl yürütmeye yönelik sorularını sormasını sağlaması gerekmektedir. Öğrenciler kitap sayesinde geliştirdikleri sorgulayıcı bakış sayesinde matematiği daha iyi anlayacaktır. Yapılan araştırmalar çalışmalar ile ders kitaplarının içeriği hem şekilsel olarak değerlendirilmekte hem de dersin mahiyetine uygun olarak görsel ve sözel unsurların birbirine uyumu ve konu akıcılığını engelleyici unsurlardan arındırılması sağlanmaktadır.

Bu araştırma ile Libya Eğitim Programı (LEP)'nda yer alan yedinci, sekizinci ve dokuzuncu sınıf matematik ders kitabı analizi ile ders kitaplarının etkinliği ve yeterliği incelenecektir. $\mathrm{Bu}$ bağlamda bu çalışma, Libya'da kullanılmakta olan ortaokul matematik ders kitaplarında (7., 8., ve 9. sınıflar) matematiksel konuların nasıl kavramsallaştırılıp ele alındığına dair ayrıntılı bir resim sağlamak için matematik konularının içerilişini, sunumunu ve yer verilen soruları analiz etmeyi amaçlamıştır. Bu amaç kapsamında aşağıdaki sorulara yanıt aranmıştır.

- Matematik ders kitaplarının içeriği, ele alınan konular, konuların sıralanışı ve konuların kitaptaki oranı (sayfa sayısı) ve matematik programında ayrılan ders süresi ile ilişkisi nasildir?

- Derslerin sunumu, teknoloji kullanımı, görsellerin uygunluk durumları nasıldır? 
- Her bir sınıf seviyesindeki ve öğrenme alanlarındaki alıştırma sorularının nitelikleri, zorluk seviyeleri, cevap türleri ve çözüm süreçleri açısından nasıldır?

\section{YÖNTEM}

\subsection{Araştırma Modeli}

Libya Matematik ders kitaplarının Libya Matematik Eğitimi öğretim programı ile uyumluluğu üzerine yapılan bu çalışmada veriler doküman incelemesi yöntemiyle toplanmıştır.

Araştırma sonucunda elde edilen bilgiler ise betimsel analiz yöntemiyle çözümlenmiştir. Nitel araştırmada üzerinde çalışılan araştırma konusuyla ilgili yazılı, görsel araç-gereç ve malzemeler araştırma için önemli veri kaynaklarıdır. Doküman incelemesi ise nitel araştırma yöntemlerinden biridir (Yıldırım \& Şimşek, 2011). Çalışmada betimsel analiz modeli ile doküman analizi yöntemlerinden yararlanılmıştır.

\section{2. Çalışma Materyalleri}

$\mathrm{Bu}$ araştırmanın yapılması için gerekli olan veriler, çalışmanın içeriğine uygun olarak Libya'da ortaöğretimde okutulan 7,8 ve 9 . Sınıf matematik ders kitapları ile Matematik öğretim programından elde edilmiştir. Ulaşılan 3 ders kitabı araştırmacı tarafından okunmuş ve incelenmiştir.

\subsection{Verilerin Analizi}

Araştırmanın doküman incelemesi yoluyla toplanan verileri betimsel analiz yöntemiyle çözümlenmiştir. Betimsel analiz yöntemiyle toplanan veriler önceden belirlenen hipotezler kapsamında ele alınarak analiz edilmiştir.

Araştırmanın ilk aşamasında Libya ortaokul matematik ders kitaplarının içeriği, ele alınan konular, konuların sıralanışı ve konuların kitaptaki oranı (sayfa sayısı) ve matematik programında ayrılan ders süresi ile ilişkisi belirlenmiştir. Bu doğrultuda ders kitaplarında yer verilen konular sınıf seviyesine göre üniteler ve alt başlıklar şeklinde betimsel olarak sunulmuştur. Konulara verilen önem ortaya konulurken ders kitaplarında ayrılan sayfa sayısı ve ilgili programda ayrılan süreler ilişsilendirilmiş ve birbiri ile tutarlı olup olmadığı ortaya konulmuştur.

Araştırmanın ikinci sorusuna cevap vermek için konulara ait ders tasarımı açıklanmıştır. Derslerin sunumunda yer verilen aşamalar örnek durumlarla açıklanmıştır. Matematik öğretiminde yer verilen teknolojiler ve görsellerin uygunluk durumları da bu başlık altında ele alınmıştır. Bir görsel konunun öğretimine veya problemin çözümüne direkt katkıda bulunuyorsa uygun bulunmuyorsa uygun değil şeklinde kodlanmıştır.

Her bir sınıf seviyesindeki ve öğrenme alanlarındaki alıştırma sorularının nitelikleri, karmaşıklık seviyeleri, cevap türleri ve çözüm süreçlerinin belirlendiği son araştırması sorusuna cevap vermek için NAEP 2007 çerçevesinde ele alınan ve soruların zorluk düzeylerine ait açıklamaları içeren kriterler kullanılmıştır. Cevap türleri belirlenirken Okay ve İncikabi (2018) tarafindan kullanılan temalara yer verilmiştir. Cevabı sayılar oluşturuyorsa; sayısal cevap, bilinmeyen ve sembol içeriyorsa; Cebirsel İfade, cevabı bir tablo içerisinde sunma zaruriyeti bulunuyorsa; Tablo, grafik şeklinde ifade gerektiriyorsa; Grafik, kelimelerle ifade gerekiyorsa; Sözel, alt kategorileri seçilmiştir. Zhu ve Fan (2006) problemlerde işlemsel gereklilik boyutunu tek basamaklı problemler ve çok basamaklı problemler olarak ikiye ayırmıştır. Bu çalışmada ise problem çözümü için gereken işlem bir tane ise tek adım, birden fazla işlem birlikte 
kullanılarak çözüme ulaşılıyorsa çok adım olarak verilere işlenmiştir. Kodlamalardan elde edilen veriler betimsel istatistikler (yüzde ve frekans) kullanılarak sunulmuştur. Aşağıda örnek kodlamalara ilişkin ders kitabı içerikleri sunulmuştur.

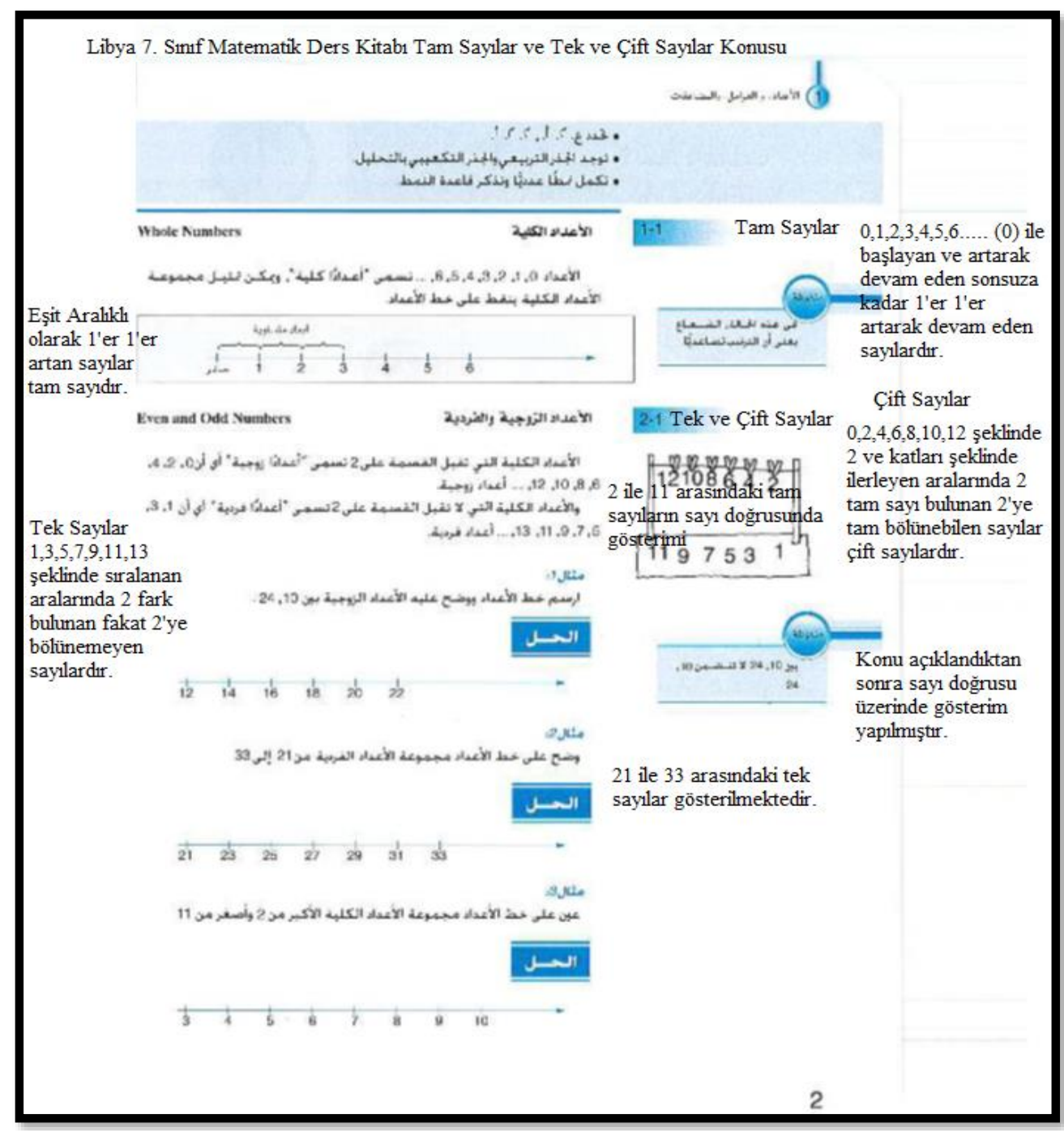

Şekil 1. Tamsayılar Konusu Sayfa 2

Şekil 1 tamsayılar konusuna ait örnek bir ders durumu ele alınmıştır. Tam sayılar konusu 1 adet konu anlatımlı soru ile başlanmış ve tam sayının sayı doğrusu üzerinde gösterimi verilmiştir. Ardından Tek sayılar ve çift sayılar konusuna geçilmiş ve birer cümle ile bu konuların konu anlatımları verilmiş ve sayfa sonunda üç adet soru ile pekiştirme yapılmıştır. Her hangi bir teknoloji kullanımı söz konusu değildir. Yer verilen görseller konunun anlaşılmasına katkıda bulunduğu için ilişkili görsel olarak kodlanmıştır. Bu örnek bilinen bir algoritmanın uygulanmasını içerdiği için zorluk düzeyi düşük olarak kodlanmıştır. İşlem birden fazla adım içerdiği için çok adım olarak ele alınmış cevap numerik olduğu için sayısal cevap olarak kodlanmıştır.

\section{3-BULGULAR}

Bu bölümde Libya Matematik Öğretim Programı ve okutulan matematik ders kitaplarının uyumluluğu incelenmiştir. Ders kitapları görsel uygunluk düzeyi, ders kitaplarında teknoloji kullanımı ve araştırma sorularının yapısı ele alınmıştır. 


\section{1-Öğretim Programı ve Kitap Karşılaştırması}

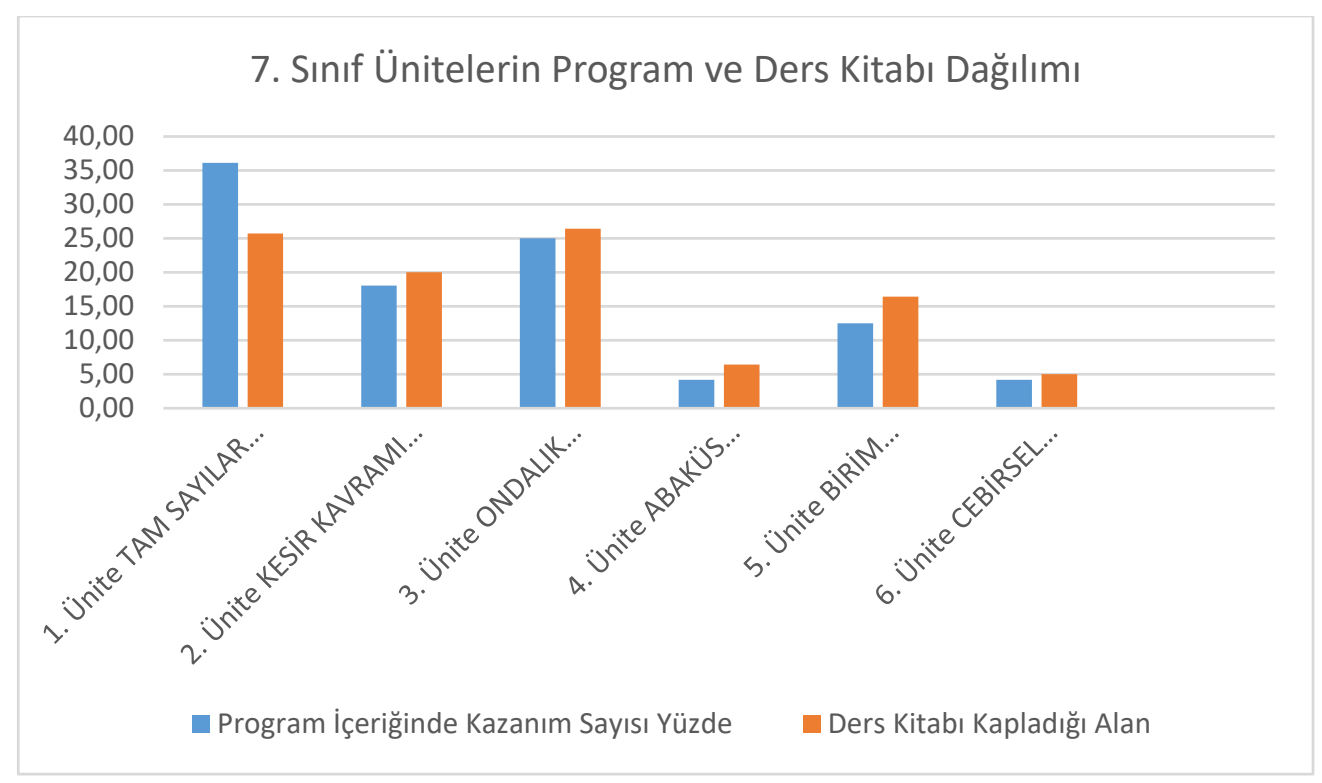

Şekil 2.7.Sınıf Ünitelerin Öğretim Programı ve Kitap Karşılaştırması

Tam sayılar konusuna programda ayrılan süre ile ders kitabındaki sayfa sayısı değerlerinin karşılaştırmasına baktığımızda kazanımların sayfa sayısından net bir şekilde farklılık oluştuğu görülmektedir. Bu durumu ortaya koyan sebeplerden birisi tam say1lar konusunda verilen kazanımlar anlatılırken öğrencilerin defterlerinde işlem yapabileceği düzende çok fazla alıştırma sorusu bulunmaktadır. Bu sorular belli bir düzen içinde verilerek sayfa verimli bir şekilde kullanılmıştır. Ayrıca diğer konuların başlangıçtaki üniteden temellendirildiği düşünüldüğünde diğer ünitelerde daha önce yer alan birçok temel bilgi diğer ünitelerde kazanımlarda yer almasına rağmen yoğun olarak işlenmemiştir. Diğer ünitelerdeki kazanımlar ile ders kitabı ilişkisi uyumlu bir şekilde dağılım göstermektedir. 


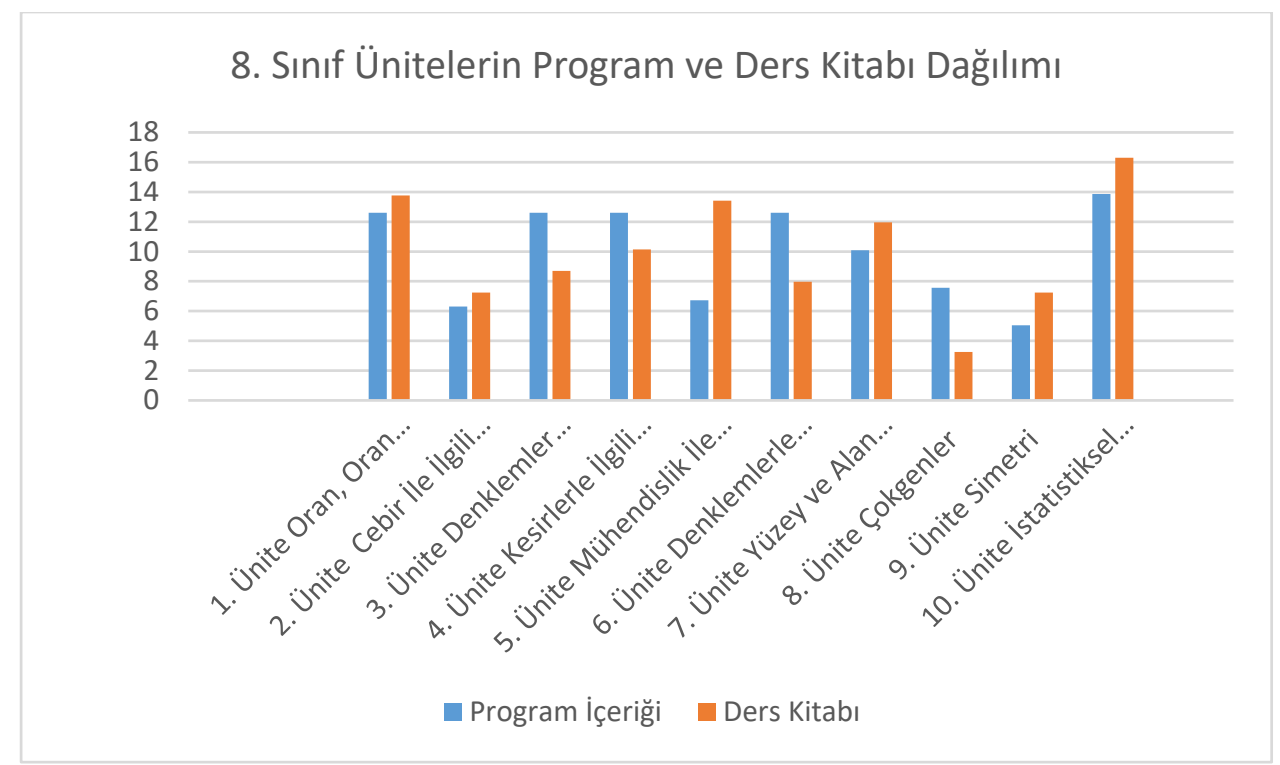

Şekil 3. 8. Sınıf Ünitelerin Öğretim Programı ve Kitap Karşılaştırması

Şekil 2 8. Sinıf program ve ders kitapları arasındaki uyumluluk dağılımı grafikleştirilmiştir. Ünite 3, 4, 6 ve 8'de ders kitabındaki sayfa sayısı ile kazanım arasındaki ilişkiye baktı̆̆ımızda kazanımların fazla olduğu ancak sayfa sayısının az olduğu görülmektedir. Yukarıda da bahsedildiği üzere aradaki ilişskinin ters yönde oluşu içeriklerdeki şekilsel unsurlardan kaynaklanmaktadır. Diğer ünitelerdeki kazanımlar ile ders kitabı ilişkisi uyumlu bir şekilde dağılım göstermektedir.

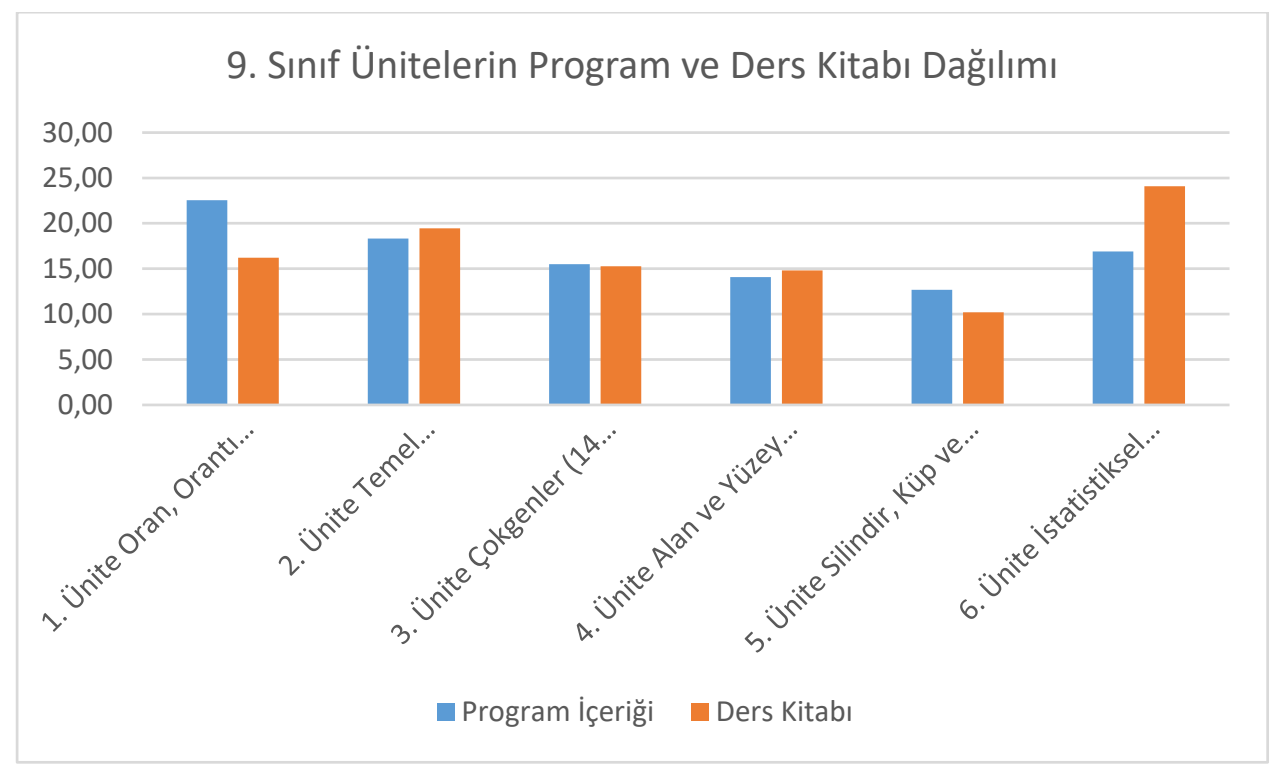

Şekil 4.9. Sınıf Ünitelerin Öğretim Programı ve Kitap Karşılaştırması

Şekil 4'te 8. Sınıf program ve ders kitapları arasındaki uyumluluk dağılımı grafikleştirilmiştir. Ünite 1, 3, ve 5'te ders kitabındaki sayfa sayısı ile kazanım arasındaki ilişkiye baktığımızda kazanımların fazla olduğu ancak sayfa sayısının az olduğu görülmektedir. Yukarıda da bahsedildiği üzere aradaki ilişkinin ters yönde oluşu içeriklerdeki şekilsel unsurlardan kaynaklanmaktadır. Diğer ünitelerdeki kazanımlar ile ders kitabı ilişkisi uyumlu bir şekilde dağılım göstermektedir. Ders kitapların tamamında dikkat çeken önemli bir husus da alıştırma 
soruları gibi öğrencilerin dersi kavramasına yönelik genel tekrar mahiyetindeki unsurlar çözümsüz olarak verilmiştir. Bu konular ilgili ders saatlerinde ödev kontrolü olarak geçirilen zaman diliminde tekrar edilip çözümlerin sunumuna yönelik olarak özel hazırlanmıştır. Öğretim programı içeriğindeki kazanımlar ve Bakanlık tarafından oluşturulan ders kitapları birbirleriyle uyumludur.

\section{2-Ders Kitaplarının Görsel Uygunluk Düzeylerine İlişkin Bulgular}

$\mathrm{Bu}$ bölümde ders kitabında yer alan görsellerin içerikle uyumluluğu ele alınmış olup konu ve ünite bazında toplam görsel sayısı ve görsel uyum oranları Tablo 1'de yer almaktadır.

Tablo 1. Ortaokul Matematik Ders Kitabı Görsellerin İçerikle Uyumuna İlişkin Dağılım

\begin{tabular}{|c|c|c|c|}
\hline Sinif & Üniteler & Toplam Görsel & Görseller \\
\hline \multirow{6}{*}{ 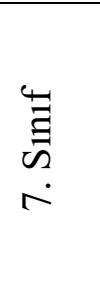 } & Tam Sayılar ve Sayılarla İlgili Diğer Kavramlar & 76 & 92,11 \\
\hline & Kesir Kavramı & 57 & 89,47 \\
\hline & Ondalık Sayılar & 31 & 70,97 \\
\hline & Abaküs Kullanımı & 4 & 75,00 \\
\hline & Birim Dönüşümleri Ve Ölçme İşlemi & 28 & 78,57 \\
\hline & Cebirsel İşlemler & 1 & 100,00 \\
\hline \multirow{10}{*}{ 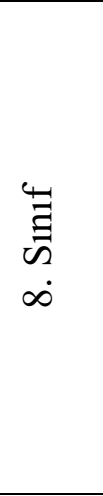 } & Oran, Oran Orant1, Basit Finansal İşlemler & 36 & 66,67 \\
\hline & Cebir İle İlgili İşlemler & 38 & 92,11 \\
\hline & Denklemler & 25 & 80,00 \\
\hline & Kesirlerle İlgili Cebirsel İşlemler & 68 & 94,12 \\
\hline & Mühendislik İle İlgili Matematiksel İşlemler & 113 & 93,81 \\
\hline & Denklemlerle İlgili Cebirsel İşlemler & 39 & 94,87 \\
\hline & Yüzey Ve Alan Hesaplamaları (Geometrik & 137 & 95,62 \\
\hline & Çokgenler & 37 & 91,89 \\
\hline & Simetri & 184 & 96,20 \\
\hline & İstatistiksel Ortalamalar & 146 & 95,89 \\
\hline \multirow{6}{*}{ 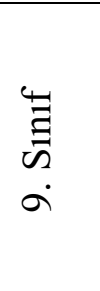 } & Oran, Orantı Kesirler ve Yüzde İşlemleri & 79 & 70,89 \\
\hline & Temel Geometri & 257 & 84,82 \\
\hline & Çokgenler & 197 & 86,29 \\
\hline & Alan ve Yüzey Hesaplamaları & 165 & 84,85 \\
\hline & Silindir, Küp ve Diğer Kübik Cisimler & 80 & 92,50 \\
\hline & İstatistiksel Grafiklerin Yorumlanmas1 & 177 & 90,96 \\
\hline
\end{tabular}

7. Sınıf 8. Sınıf ve 9. Sınıf Libya Matematik ders kitabının içeriğinde yer alan görsellerin uygun olup olmadığına ilişkin olarak yapılan incelemede aşağıdaki şekil 5 oluşturulmuştur. 


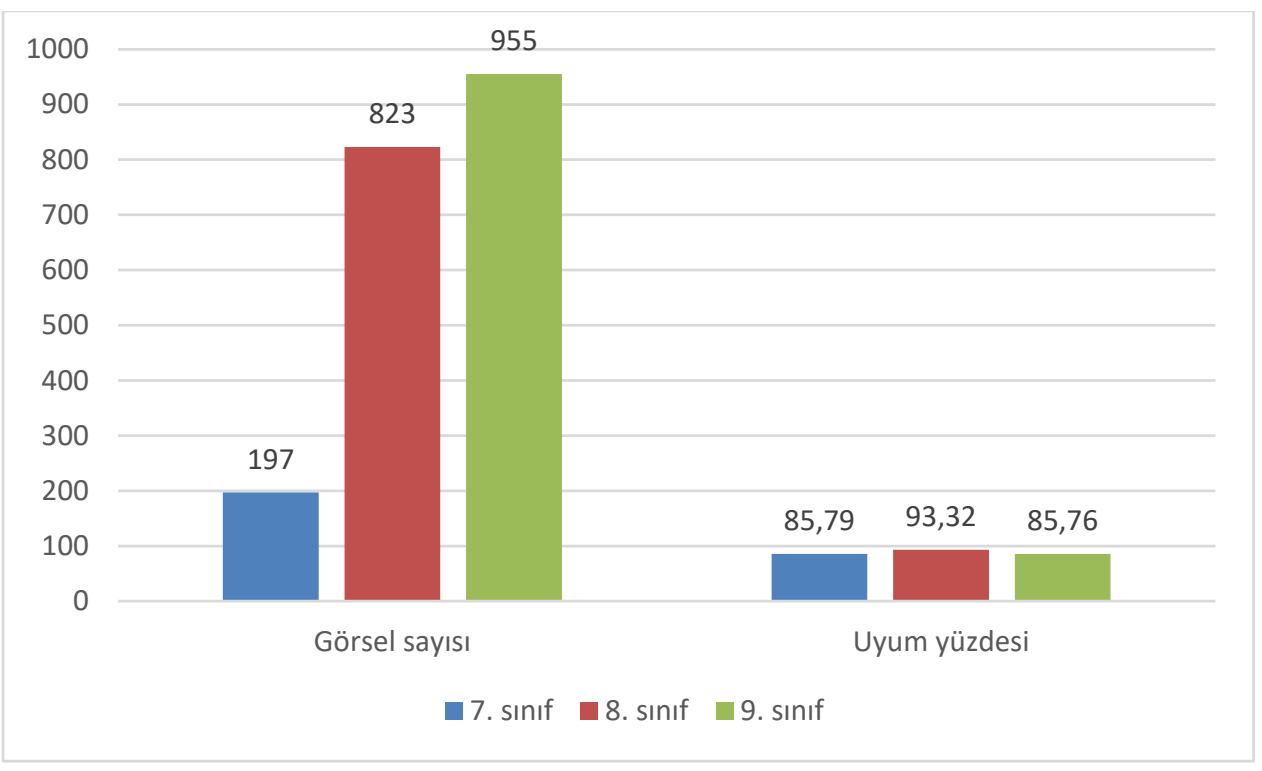

Şekil 5.Görsellerin uygunluk durumu

Grafiğe göre sınıf seviyesine göre görsel kullanımında artış olmuştur. Özellikle 7. Sınıf seviyesine göre diğer kademelerde ders kitaplarında görsel kullanımında önemli artma belirlenmiştir. Bununla birlikte görsellerin büyük çoğunluğu ilgili içerikle (\%85-\%95 arası değişen uyum yüzdesiyle) uyumlu bulunmuştur.

Ortaokul matematik ders kitaplarında kullanılan görsellerin içerikle uyumunun üniteler bazında dağılımı Tablo 2'de detaylandırılmıştır. 7. Sınıf Libya Matematik ders kitabında cebirsel işlemler konusunda \%100 uyumun olduğu Tam Sayılar ve Sayılarla İlgili Diğer Kavramlar ünitesinde \% 92,11, Kesir Kavramı ünitesinde \%89,47, Birim Dönüşümleri Ve Ölçme İşlemi ünitesinde 78,57, Abaküs Kullanımı ünitesinde \%75,00, Ondalık Sayılar ünitesinde \%70,97 uyumun olduğu görülmektedir.

8. Sınıf Libya Matematik ders kitabında "Simetri" ünitesinin \%96,20, "Yüzey ve Alan Hesaplamaları" ünitesinin \%95,62, "Denklemlerle İlgili Cebirsel İşlemler" ünitesinin \%94,87, “Kesirlerle İlgili Cebirsel İşlemler” ünitesinin \%94,12, "Mühendislik İle İlgili Matematiksel İşlemler" ünitesinin \%93,81, “Cebir İle İlgili İşlemler” ünitesinin 92,11, "Denklemler" ünitesinin \%80,00 ve "Oran, Oran Orant1, Basit Finansal İşlemler” ünitesinin ise \%66,67 olduğu görülmektedir. En fazla görsel uyumsuzluğu "Oran, Oran Orantı, Basit Finansal İşlemler" ünitesi olduğu en uyumlu ünitenin ise "Simetri" ünitesinin olduğu görülmektedir. Tablodaki veriler üzerinden ünitelerin görsel uygunluk düzeylerinin karşılaştırılmaları mümkün değildir. Çünkü ünitelerde yer alan görsel sayıları ve konunun kapsamı farklılık göstermektedir.

9. Sınıf Libya Matematik ders kitabında "Silindir, Küp ve Diğer Kübik Cisimler" ünitesinde $\% 92,50$, "İstatistiksel Grafiklerin Yorumlanması" ünitesinde \%90,96, "Çokgenler" ünitesinde $\% 86,29$, "Alan ve Yüzey Hesaplamaları" ünitesinde \%84,85, "Temel Geometri" ünitesinde \%84,82 ve "Oran, Orant1 Kesirler ve Yüzde İşlemleri" ünitesinde \%70,89 görsel uyumun olduğu görülmektedir. En yüksek uyum oranı "İstatistiksel Grafiklerin Yorumlanması" iken en düşük görsel uyum "Oran, Orantı Kesirler ve Yüzde İşlemleri" ünitesindedir. Tablodaki veriler üzerinden ünitelerin görsel uygunluk düzeylerinin karşılaştırılmaları mümkün değildir. Çünkü ünitelerde yer alan görsel sayıları ve konunun kapsamı farklılık göstermektedir. 
Görsellerin uygunluk düzeylerinin belirlenmesine ilişkin örnek içerik aşağıdaki gibidir;
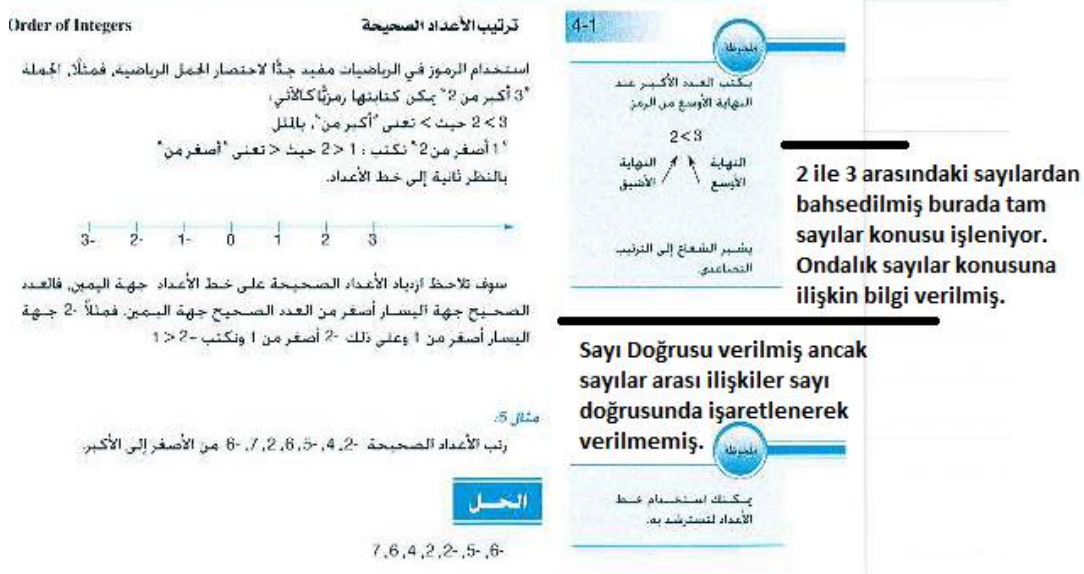

Şekil 6.Uygun olmayan görsel (7. Sınıf Matematik Ders Kitabı Sayfa 4)

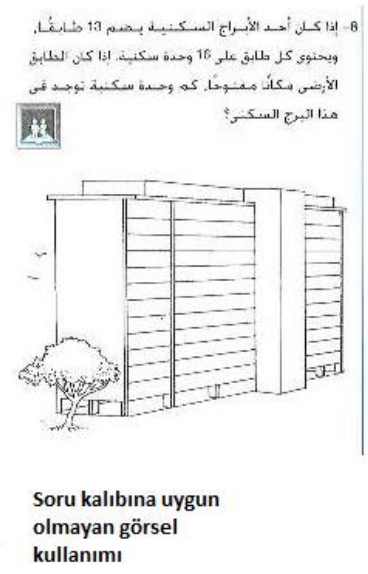

Şekil 7. 7. Sınıf Matematik Ders Kitabı Sayfa 19

Üst kısımda ağacın 5 metre yüksekliğinde olduğunu belirten bir görselde binanın ne amaçla konulduğu belli değildir. Bu nedenle görselde kafa karışıklığı oluşturan bir durum söz konusudur. Ağacın uzunluğunu anlatmak için bina görseline ihtiyaç yoktur. Ayrıca 5 metre olarak bahsedilen ağaç binanın 5. Katına ulaşmıştır. Her bir katın 1 metre olması olağan değildir.

\subsection{Ders kitaplarında teknoloji kullanımı}

Bu bölümde ders kitabında yer alan konu ve içerikler ile alıştırma sorularına ilişkin teknoloji kullanım durumları ele alınmıştır. Çalışmada yer alan örnek sayfa Şekil 8'de yer almaktadır. 

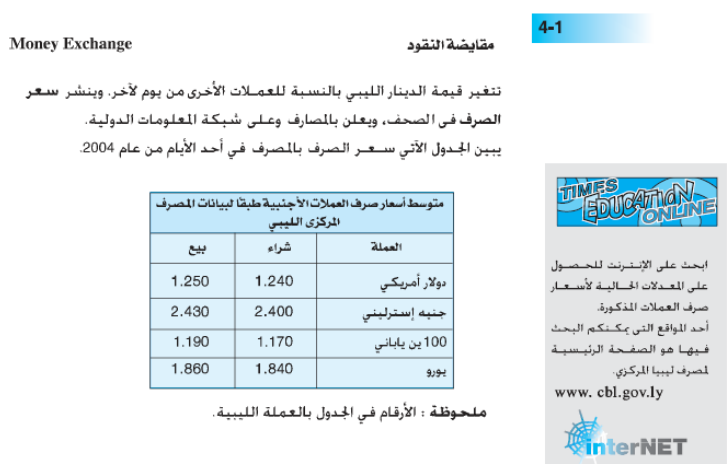

Şekil 8. 8. Sınıf Libya Matematik Ders Kitabında Teknoloji Kullanımı

Para dönüşümlerine ilişkin konunun işlendiği görselde www.cbl.gov.ly adlı internet sitesinde yönlendirme yapılmıştır. Libya Merkez bankasının sitesi olan ilgili adres döviz kurlarının takip edilebileceği bir sitedir. Görselde yer alan tabloda döviz alış ve satış kurları bulunmaktadır. Öğrenciler buradan kurlara ilişkin bilgi edinebilirler.

\subsection{Alıştırma Sorularının Nitelikleri, Zorluk Seviyeleri, Cevap Türleri ve Çözüm Süreçlerine İlişkin Bulgular}

Bu bölümde ders kitabında yer alan Alıştırma Sorularının Nitelikleri, Zorluk Seviyeleri, Cevap Türleri ve Çözüm Süreçlerine İlişkin Bulgular yer almaktadır. Alıştırmaların zorluk derecesi düşük, orta ve yüksek derecede belirlenmiştir. Grafikte ortaokul matematik ders kitaplarında yer verilen soruların zorluk düzeylerine yönelik genel durum verilmiştir.

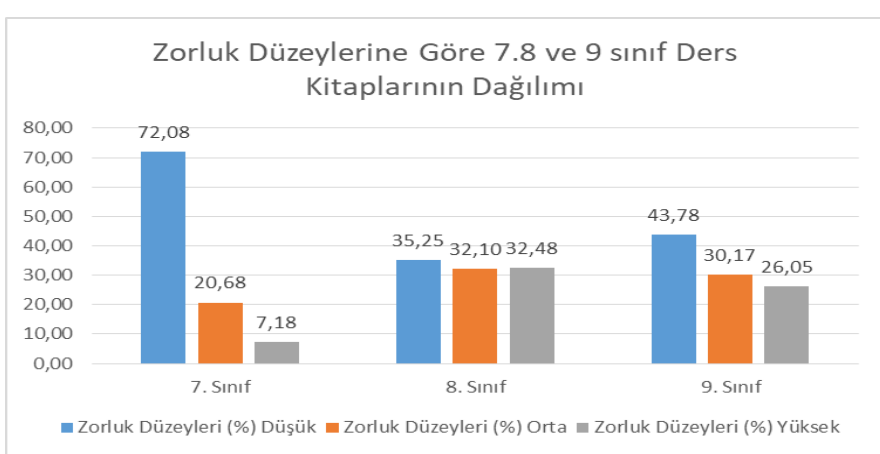

Şekil 9. Zorluk düzeylerinin dağılımı (\%)

Genel olarak her sınıf kademesinde düşük zorluk düzeyindeki sorular daha fazla yer almıştır. Özellikle bu durum 7. Sınıf ders kitabında daha belirgin haldedir. Yüksek düzeyde soru dağılımları en fazla 8. Sınıf seviyesinde iken $(\% 32,48)$ en az 7 . Sınıf seviyesindedir $(\% 7,18)$. Bununla birlikte soruların zorluk seviyeleri 8. ve 9. Sinıf matematik ders kitaplarında daha dengeli bir dağılım göstermektedir.

Tablo 2. Zorluk Derecelerine İlişkin Sınıf ve Ünite Bazında Bulgular

\begin{tabular}{|c|c|}
\hline Sinif & Üniteler \\
\hline
\end{tabular}


Düşük Orta Yüksek

\begin{tabular}{|c|c|c|c|c|c|}
\hline \multirow{6}{*}{$\begin{array}{l}\bar{\Xi} \\
\stackrel{\Xi}{\circ}\end{array}$} & $\begin{array}{l}\text { Tam Sayılar ve Sayılarla İlgili Diğer } \\
\text { Kavramlar }\end{array}$ & 394 & 60,15 & 28,93 & 10,92 \\
\hline & Kesir Kavramı & 500 & 57,60 & 31,00 & 11,00 \\
\hline & Ondalık Sayılar & 535 & 65,61 & 18,32 & 16,07 \\
\hline & Abaküs Kullanımı & 101 & 90,10 & 9,90 & 0,00 \\
\hline & Birim Dönüşümleri ve Ölçme İşlemi & 330 & 76,67 & 21,21 & 2,12 \\
\hline & Cebirsel İşlemler & 102 & 82,35 & 14,71 & 2,94 \\
\hline \multirow{10}{*}{$\begin{array}{l}\bar{\Xi} \\
\infty \\
\infty\end{array}$} & Oran, Oran Orant1, Basit Finansal İşlemler & 537 & 55,68 & 24,39 & 19,93 \\
\hline & Cebir İle İlgili İşlemler & 212 & 57,08 & 16,04 & 26,89 \\
\hline & Denklemler & 584 & 40,07 & 37,16 & 22,60 \\
\hline & Kesirlerle İlgili Cebirsel İşlemler & 482 & 40,04 & 40,04 & 19,92 \\
\hline & Mühendislik İle İlgili Matematiksel İşlemler & 469 & 17,06 & 36,25 & 46,70 \\
\hline & Denklemlerle İlgili Cebirsel İşlemler & 252 & 35,32 & 33,33 & 29,76 \\
\hline & Yüzey ve Alan Hesaplamaları & 208 & 33,17 & 25,00 & 41,83 \\
\hline & Çokgenler & 35 & 22,86 & 28,57 & 48,57 \\
\hline & Simetri & 216 & 25,46 & 35,19 & 39,35 \\
\hline & İstatistiksel Ortalamalar & 202 & 25,74 & 45,05 & 29,21 \\
\hline \multirow{7}{*}{$\begin{array}{l}\bar{B} \\
\bar{B} \\
\sigma^{\circ}\end{array}$} & Oran, Orantı Kesirler Ve Yüzde İşlemleri & 252 & 53,97 & 22,62 & 23,41 \\
\hline & Temel Geometri & 255 & 50,59 & 30,59 & 18,82 \\
\hline & Çokgenler & 139 & 40,29 & 29,50 & 30,22 \\
\hline & Alan ve Yüzey Hesaplamaları & 206 & 38,83 & 29,13 & 32,04 \\
\hline & Silindir, Küp ve Diğer Kübik Cisimler & 148 & 35,14 & 37,16 & 27,70 \\
\hline & İstatistiksel Grafiklerin Yorumlanması & 253 & 43,87 & 32,02 & 24,11 \\
\hline & Genel Toplam & 6412 & 47,85 & 29,51 & 22,54 \\
\hline
\end{tabular}

7. Sınıf Matematik ders kitabında yüksek zorluk düzeyine sahip soruların dağılımı en fazla ondalık sayılar ünitesinde $(\% 16,07)$ mevcut iken abaküs kullanımı ünitesinde hiçbir soru yüksek düzeyde zorluğa sahip değildir. Bu ünitedeki soruların önemli bir kısmı $(\% 90,10)$ düşük düzeyde kalmıştır. Bununla birlikte kesir kavramı ünitesinde orta düzey sorulara bu sınıf seviyesinde daha fazla oranda yer verilirken (\%31), bu ünitede düşük düzey sorulara bu sinıftaki diğer ünitelere göre daha az yer verilmiştir.

8. Sınıf Matematik ders kitabında yüksek zorluk düzeyine sahip soruların dağılımı en fazla Mühendislik İle İlgili Matematiksel İşlemler ünitesinde $(\% 46,70)$ mevcut iken Kesirlerle İlgili Cebirsel İşlemler ünitesinde diğer ünitelere göre daha az yüksek seviyede alıştırma sorusu 
bulunmaktadır. Orta düzeyde zorluk derecesine sahip alıştırma sorusu ise en fazla İstatistiksel Ortalamalar ünitesinde $(\% 45,05)$ iken düşük zorluk düzeyde alıştırma sorusu en fazla Cebir İle İlgili İşlemler $(\% 57,08)$ ünitesinde yer almaktadır.

9. Sınıf Matematik ders kitabında yüksek zorluk düzeyine sahip soruların dağılımı en fazla Alan ve Yüzey Hesaplamaları ünitesinde $(\% 32,04)$ mevcut iken Temel Geometri ünitesinde diğer ünitelere göre daha az yüksek $(\% 18,82)$ seviyede alıştırma sorusu bulunmaktadır. Orta düzeyde zorluk derecesine sahip alıştırma sorusu ise en fazla Silindir, Küp ve Diğer Kübik Cisimler ünitesinde $(\% 37,16)$ iken düşük zorluk düzeyde alıştırma sorusu en fazla Oran, Orantı Kesirler Ve Yüzde İşlemleri $(\% 53,97)$ ünitesinde yer almaktadır.

\subsection{Cevap Türlerine İlişkin Bulgular ve Yorumlar}

$\mathrm{Bu}$ bölümde ders kitabında yer alan alıştırma soruları ve bunlara ilişkin çözümlemelerin türlerine ilişkin bulgular yer almaktadır.

Libya Matematik Ders Kitabında yer alan alıştırma sorularının çözümleri cevap türleri bakımından NAEP 2007 çerçevesinde "sayısal cevap", "sözel cevap", "cebirsel ifade" ve "tablo grafik şekil" içerip içermediği yönünden incelenmiş olup aşağıda tabloda ortaokul matematik ders kitaplarında yer verilen soruların her bir alt konu başlığındaki yüzdelik dağılımı verilmiştir.

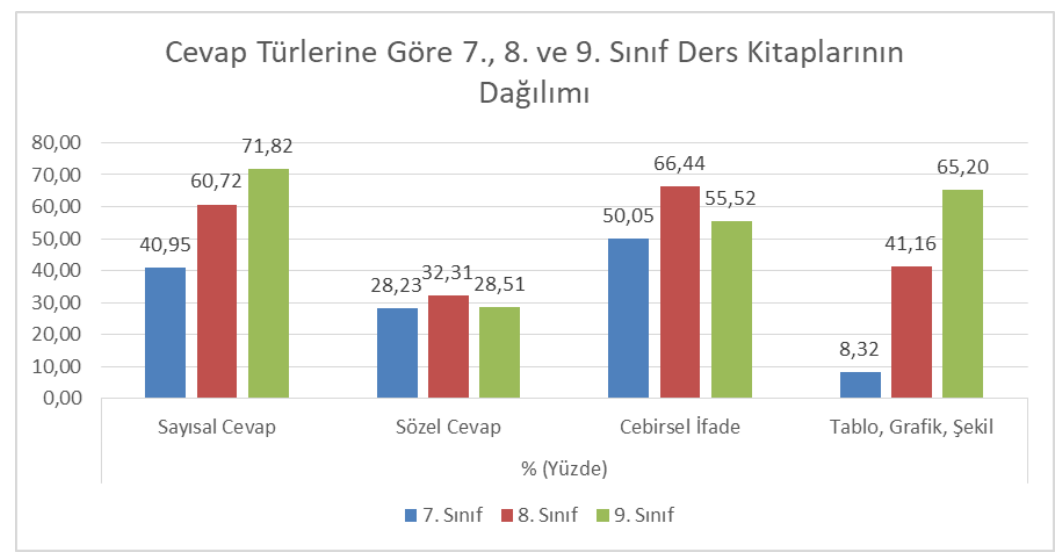

Şekil 10. Cevap Türlerine Göre Genel Dağılım

Genel olarak her sınıf kademesinde cevap türlerine ilişkin dağılım incelendiğinde (Şekil 11) 7. Sınıf matematik ders kitabında daha az tablo, şekil grafik vb unsurlar yer alırken cebirsel ifade ve sayısal cevap çoğunluktadır. 8. Sınıfta sayısal cevap ve cebirsel ifade yer alırken diğer sınıf düzeylerine göre de daha yüksek düzeydedir. 9. Sınıf matematik ders kitabında ise sayısal cevap, cebirsel ifade ve tablo, şekil grafik unsuru yoğun olarak bulunmaktadır. Sayısal cevap ve tablo, şekil ve grafik unsuru 9. Sinıfta diğer sınıflara göre yüksek düzeydedir.

Libya Matematik Ders Kitaplarında yer alan soruların cevap türlerine göre yüzdesel dağılımı üniteler bazında Tablo 3'de yer almaktadır.

Tablo 3. Cevap Türlerine İlişkin Sınıf ve Ünite Düzeyinde Bulgular

\begin{tabular}{|c|c|c|c|c|c|c|}
\hline \multirow{2}{*}{ Sinıf } & \multirow{2}{*}{ Üniteler } & \multirow{2}{*}{$\begin{array}{l}\text { Alıştırma } \\
\text { Sayısı }\end{array}$} & \multicolumn{3}{|c|}{ \% (Yüzde) } & \multirow[b]{2}{*}{ Tablo } \\
\hline & & & Sayisal & Sözel & Cebirsel & \\
\hline \multirow{2}{*}{\multicolumn{2}{|c|}{ 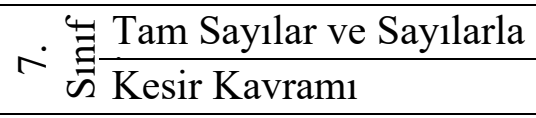 }} & 394 & 35,79 & 0 & 64,21 & 19,29 \\
\hline & & 500 & 3,2 & 1,6 & 88 & 11,4 \\
\hline
\end{tabular}




\begin{tabular}{|c|c|c|c|c|c|c|}
\hline & Ondalık Sayılar & 535 & 82,24 & 7,66 & 42,43 & 5,79 \\
\hline & Abaküs Kullanımı & 101 & 0 & 100 & 0 & 3,96 \\
\hline & Birim Dönüşümleri ve & 330 & 34,24 & 50,3 & 15,45 & 8,48 \\
\hline & Cebirsel İşlemler & 102 & 90,2 & 9,8 & 90,2 & 0,98 \\
\hline & Toplam & 1962 & 40,88 & 16,62 & 54,18 & 10,04 \\
\hline \multirow{11}{*}{$\begin{array}{l} \\
\dot{\Xi} \\
\infty\end{array}$} & Oran, Oran Orant1, Basit & 537 & 96,65 & 2,61 & 90,32 & 6,7 \\
\hline & Cebir İle İlgili İşlemler & 212 & 87,74 & 9,91 & 100 & 17,92 \\
\hline & Denklemler & 584 & 100 & 0 & 100 & 4,28 \\
\hline & Kesirlerle İlgili Cebirsel & 482 & 100 & 0 & 87,14 & 14,11 \\
\hline & Mühendislik İle İlgili & 469 & 95,1 & 4,9 & 95,1 & 24,09 \\
\hline & Denklemlerle İlgili Cebirsel & 252 & 3,57 & 96,43 & 95,63 & 15,48 \\
\hline & Yüzey ve Alan & 208 & 9,62 & 90,38 & 17,31 & 65,87 \\
\hline & Çokgenler & 35 & 34,29 & 65,71 & 57,14 & 105,71 \\
\hline & Simetri & 216 & 0 & 33,33 & 0 & 85,19 \\
\hline & İstatistiksel Ortalamalar & 202 & 80,2 & 19,8 & 21,78 & 72,28 \\
\hline & Toplam & 2660 & 90,98 & 23,46 & 93,53 & 30,94 \\
\hline \multirow{8}{*}{ 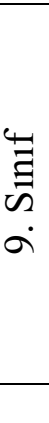 } & Oran, Orantı Kesirler Ve & 252 & 100 & 0 & 100 & 31,35 \\
\hline & Temel Geometri & 255 & 71,37 & 28,63 & 0 & 81,18 \\
\hline & Çokgenler & 139 & 57,55 & 42,45 & 33,09 & 84,89 \\
\hline & Alan ve Yüzey & 206 & 100 & 0 & 100 & 76,21 \\
\hline & Silindir, Küp ve Diğer & 148 & 100 & 0 & 100 & 47,97 \\
\hline & İstatistiksel Grafiklerin & 253 & 1,98 & 100 & 0 & 69,57 \\
\hline & Toplam & 1253 & 69,67 & 30,73 & 52,04 & 64,49 \\
\hline & Genel Toplam & 5875 & 69,7 & 22,72 & 71,54 & 31,11 \\
\hline
\end{tabular}

\section{6. İşlem Gerekleri}

Bu bölümde ders kitabında yer alan alıştırma sorularının çözümünde tek işlem ve birden fazla (çok aşamalı işlem) olarak yapılan kodlamalara ilişkin tablo ve grafik yer almakta olup analiz sonucunda elde edilen veriler yorumlanmıştır.

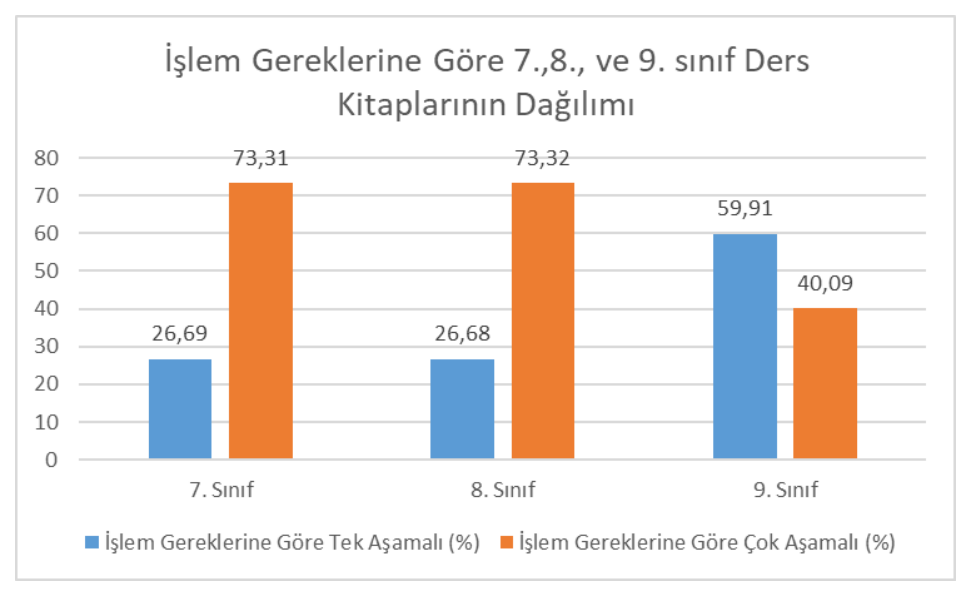

Şekil 11. İşlem Gereklerine göre Genel Dağılım (\%)

Genel olarak işlem gereklerine göre dağılım incelendiğinde 7. ve 8. Sınıfta çok aşamalı işlem gereklerine sahip alıştırma soru sayısı bulunmakta iken 9. Sınıfta tek aşamalı işlem gereğine 
sahip alıştırma soru sayısı yoğunluktadır.8 sınıfta çok aşamalı işlem gereklerine sahip soru sayısı diğer sınıf düzeylerine göre daha fazladır.

Tablo 4. İşlem Gerekleri Tüm Sınıf ve Ünite Bazında Değerlendirme

\begin{tabular}{|c|c|c|c|c|c|c|}
\hline \multirow[b]{2}{*}{ Sinif } & \multirow{2}{*}{ Ünite } & \multirow{2}{*}{$\begin{array}{l}\text { Alıştırma } \\
\text { Sayısı }\end{array}$} & \multicolumn{3}{|c|}{ İşlem Gerekleri } & \multirow[b]{2}{*}{$\%$} \\
\hline & & & Tek Aşamalı & $\%$ & Çok Aşamalı & \\
\hline \multirow{17}{*}{ 7. Sinıf } & $\begin{array}{l}\text { Tam Sayılar Ve Sayılarla } \\
\text { İlgili Diğer Kavramlar }\end{array}$ & 394 & 39 & 9,898 & 253 & 64,21 \\
\hline & Kesir Kavramı & 500 & 16 & 3,2 & 484 & 96,8 \\
\hline & $\overline{\text { Ondalık Sayılar }}$ & 535 & 171 & 31,96 & 69 & 12,9 \\
\hline & Abaküs Kullanımı & 101 & 51 & 50,5 & 0 & 0 \\
\hline & $\begin{array}{l}\text { Birim Dönüşümleri Ve } \\
\text { Ölçme İşlemi }\end{array}$ & 330 & 74 & 22,42 & 39 & 11,82 \\
\hline & Cebirsel İșlemler & 102 & 43 & 42,16 & 49 & 48,04 \\
\hline & Toplam & 1962 & 394 & 20,08 & 894 & 45,57 \\
\hline & $\begin{array}{l}\text { Oran, Oran Orantı, Basit } \\
\text { Finansal İşlemler }\end{array}$ & 537 & 22 & 4,1 & 515 & 95,9 \\
\hline & Cebir İle İlgili İşlemler & 212 & 24 & 11,32 & 188 & 88,68 \\
\hline & Denklemler & 584 & 0 & 0 & 584 & 100 \\
\hline & $\begin{array}{l}\text { Kesirlerle İlgili Cebirsel } \\
\text { İşlemler }\end{array}$ & 482 & 28 & 5,81 & 454 & 94,19 \\
\hline & $\begin{array}{l}\text { Mühendislik İle İlgili } \\
\text { Matematiksel İşlemler }\end{array}$ & 469 & 23 & 4,9 & 446 & 95,1 \\
\hline & $\begin{array}{l}\text { Denklemlerle İlgili } \\
\text { Cebirsel İşlemler }\end{array}$ & 252 & 29 & 11,51 & 223 & 88,49 \\
\hline & $\begin{array}{l}\text { Yüzey Ve Alan } \\
\text { Hesaplamaları (Geometrik } \\
\text { Hesaplamalar) }\end{array}$ & 208 & 18 & 8,65 & 190 & 91,35 \\
\hline & Çokgenler & 35 & 29 & 82,86 & 6 & 17,14 \\
\hline & Simetri & 216 & 216 & 100 & 0 & 0 \\
\hline & İstatistiksel Ortalamalar & 202 & 76 & 37,62 & 126 & 62,38 \\
\hline \multirow[t]{5}{*}{ 8. Sinıf } & Toplam & 2660 & 443 & 14,54 & 2217 & 85,46 \\
\hline & $\begin{array}{l}\text { Oran, Orantı Kesirler Ve } \\
\text { Yüzde İşlemleri }\end{array}$ & 252 & 92 & 36,51 & 160 & 63,49 \\
\hline & Temel Geometri & 255 & 243 & 95,29 & 12 & 4,71 \\
\hline & Çokgenler & 139 & 105 & 75,54 & 34 & 24,46 \\
\hline & $\begin{array}{l}\text { Alan ve Yüzey } \\
\text { Hesaplamaları }\end{array}$ & 206 & 42 & 20,39 & 164 & 79,61 \\
\hline
\end{tabular}




\begin{tabular}{|c|c|c|c|c|c|}
\hline $\begin{array}{l}\text { Silindir, Küp ve Diğer } \\
\text { Kübik Cisimler }\end{array}$ & 148 & 54 & 36,49 & 94 & 63,51 \\
\hline $\begin{array}{l}\text { İstatistiksel Grafiklerin } \\
\text { Yorumlanması }\end{array}$ & 253 & 241 & 95,26 & 12 & 4,74 \\
\hline Toplam & 1253 & 777 & 62,01 & 476 & 37,99 \\
\hline Genel Toplam & 5875 & 1614 & 27,47 & 3587 & 61,06 \\
\hline
\end{tabular}

\section{SONUÇ, TARTIŞMA ve ÖNERILER}

Sınıfta kullanılan ders kitabı öğrencilerin matematiği nasıl gördüklerini belirlemede çok önemlidir (Mukucha, 2012). Ders kitabı, öğrencilerin matematik fikirlerini iletmelerini sağlamak veya kısıtlamakta yardımcı olur. Ders kitabı, matematik dersinde verdikleri cevaplar için daha fazla açıklama ve iyi gerekçeler vermelerini gerektiren sorular sorarak, öğrencilere daha yüksek matematiksel akıl yürütmeleri önermelidir. Ders kitabı ayrıca alıştırmalar, testler, soruşturmalar ve projeler yoluyla sürekli değerlendirme meşrulaştırmalıdır. $\mathrm{Bu}$, öğrencilerin pratik yapmalarını ve dolayısıyla çalışmalarını yansıtmalarını sağlayacaktır (Aineamani, 2010). Marton ve diğ. (2004), öğretmenin odak noktasının hem öğrenmenin doğrudan nesnesi hem de öğrenmenin dolaylı nesnesi üzerinde olması gerektiğinden, öğrencilerin odak noktasının öğrenmenin doğrudan nesnesi üzerinde olması gerektiğini savunmaktadır. Ders kitab1 öğretmenin kendisi kadar bilgili olduğu gibi davranması gerektiği için (Vygotsky, 1978), aynı zamanda öğrenmenin hem doğrudan hem de dolaylı nesnesine odaklanmalıdır. Bu nedenle, ders kitabı etkinlikleri, öğrenme nesnesinin "öğrencilerin farkındalığının önüne geçecek” şekilde yapılandırılmalıdır (Marton ve ark. 2004).

Matematik ders kitaplarının öğrencinin matematik öğretimi ve öğrenmesi üzerindeki etkisi üzerine birçok araştırma yapılmıştır (Morgan, 1995; 2005; Dowling, 1996). Matematik ders kitabının sınıf içinde çok önemli bir rolü olduğundan, matematik ders kitabının öğrencinin öğrenmesi üzerinde etkili olduğu ve öğrencinin biliş düzeyine uygun bir biçimde yapılandırılması gerektiği belirtilmiştir (Aineamani ve Naicker, 2014).

Ders kitapları, alanlarında uzman olan eğitimciler tarafından hazırlanmalı ve hem öğretmenin hem de öğrencinin kullanabileceği bilgileri içermelidir. Ders kitabında verilen bilgiler öğrencinin zihinsel gelişim düzeyine uygun olmalı, konular ise somuttan soyuta, basitten karmaşığa, kolaydan zora bir sıra izlenmelidir (Sadoski, 2001).

Matematik ders kitaplarının öğrencinin matematik öğretimi ve öğrenmesi üzerindeki etkisi üzerine birçok araştırma yapılmıştır (Morgan, 1995; 2005; Dowling, 1996). Matematik ders kitabının sınıf içinde çok önemli bir rolü olduğundan, matematik ders kitabının öğrencinin öğrenmesi üzerindeki etkisi hafife alınmamalıdır. Ders kitaplarını analiz etmek için, iki teorik çerçeve kullanılmıştır. Kullanılan teorik çerçeveler Kilpatrick ve arkadaşlarının (2001) beş matematik yeterlilik teli ve Marton ve arkadaşlarının (2004) Varyasyon teorisidir. İki çerçeveden ders kitaplarını analiz etmek için kullandığımız analitik bir çerçeve geliştirdik. Ders kitabı analizinden çıkan sonuçlar, aşağıda yer almaktadır.

\subsection{Matematik Ders Kitaplarının İçeriği ve Program Uyumluluğu Açısından Değerlendirme}

Çalışma sonucunda matematik ders kitaplarının içeriği, ele alınan konular, konuların sıralanışı ve konuların kitaptaki oranı (sayfa sayısı) ve matematik programında ayrılan ders süresi ile ilişkisi ortaya konulmuştur. Bu kapsamda 7. Sınıf Libya Matematik Ders Programında bulunan 
müfredat içeriklerine ilişkin kazanımlar ve ders süresi ilişkisi ele alınmıștır. 7. Sınıf ders konularının giriş ünitesi olan tam sayılar ve sayılarla ilgili diğer kavramlar konusu temel matematik bilgilerinden biri olan sayılar konusunun derinlemesine imkân sağlayacak şekilde en yüksek kazanıma (25) sahip olduğu 7. Sınıf program içeriğinin \% 36,11'lik kısmını oluşturduğu 2. Ünite olan ondalık sayılar ünitesinin 18 kazanım ile programda en fazla kazanım içeriğine sahip ikinci ünite olduğu toplam müfredatın \% 25'ine tekabül ettiği ortaya konulmuştur. Abaküs kullanımı (3 kazanım-9 sayfa) ve cebirsel işlemler konusu (3 kazanım- 7 sayfa) ise az sayıda kazanıma ve sayfa sayısına sahiptir. 7. sınıf matematik dersi toplamda 71 kazanım 140 sayfalık bir kitap ile 216 saat ders süresine sahip olduğu Libya Matematik Ders Programından anlaşılmaktadır.

8. Sınıf Libya Matematik Ders Kitabı incelendiğinde 8. Sınıf dersinde "denklemler ile ilgili cebirsel işlemler" konusu en yüksek kazanıma (26) sahip olup, 8. Sınıf program içeriğinin \% 12,61'lik kısmını oluşturduğu (22 sayfa) ortaya çıkmıştır. En yüksek sayfa sayısına sahip üniteler sırasıyla 10. Ünite İstatistiksel Ortalamalar (45), 1. Ünite Oran, Oran Orant1, Basit Finansal İşlemler (38), 5. Ünite Mühendislik İle İlgili Matematiksel İşlemler (37), 7. Ünite Yüzey ve Alan Hesaplamaları (Geometrik Hesaplamalar) (33) şeklinde dağılmış olup diğer üniteler ise 24 sayfa ve altında sayfa sayısından oluştuğu görülmektedir. İstatistiksel ortalamalar dersinin kazanım sayısı ile ders kitabındaki sayfa sayısı karşılaştırıldığında ilişkinin ters yönde olduğu sonucuna varılmıştır. Bunun en temel sebebi ise istatistiksel işlemlerin anlatımında çok fazla şekilsel öğenin bulunmasından kaynaklandığı görülmektedir. 8. sınıf matematik dersi toplamda 113 kazanım 276 sayfalı bir kitap ile 238 ders saatinden oluşmaktadır.

9. Sınıf Libya Matematik Ders Programında bulunan müfredat içeriklerine ilişkin kazanımlar ve ders süresi ilişkisi ile matematik ders kitabı içeriği incelendiğinde "temel geometri" konusu en yüksek kazanıma (22) sahip olup, 9. Sınıf program içeriğinin \% 18,31'lik kısmını oluşturduğu 42 sayfa ile ders kitabına işlenen bu konu 39 ders saatinde işlendiği görülmüştür. Toplamda 89 kazanım 216 sayfalık bir kitap ile 213 ders saatine uygun bir biçimde programlandığı görülmektedir. Ders saati ve kazanım ilişkilerinden elde edilen sonuca göre bazı konu başlıklarının temel nitelikte olduğu ve üst sınıflarda konunun detaylandırıldığı görülmektedir. Ancak ders saati ve kazanımlar karşılaştırıldığg ders süresinin uzun olduğu görülmektedir.

\subsection{Derslerin Sunumu, Teknoloji Kullanımı, Görsellerin Uygunluk Durumları Açısından Değerlendirme}

Ders sunumlarında teknoloji kullanımının çok sınırlı olduğu ders saatleri ve kazanım ilişkilerinin daha dengeli dağılması için öğrencilerin ders dışı aktivitelere yönlendirilmesi gerektiği ve bunu sağlamak içinde bilgi teknolojilerinden yararlanılarak materyal geliştirmek gerektiği sonucuna varılabilir. Ders kitabında kullanılan görsellerde karşıt renkler kullanılarak anlamı kolaylaştıracak görsellere yer verilmesinin uygun olacağı sonucuna varılmıştır. Dane ve diğerleri tarafından yapılan ilköğretim 7. sınıf matematik ders kitaplarının incelenmesi araştırmasında kullanılan kağıt türü, resim, grafik tablo ve şekiller dünya standartlarının gerisinde kaldıkları içerik yönünden sadece yalın bilgileri içerdiği ve özellikle ders kitaplarının öğretim strateji, yöntem ve teknikleri bakımından yetersiz olduğu yalnızca sunuş yöntemini içerdiği ortaya konulmuştur (Dane, Doğar ve Balkı, 2004). Çalışmamızda da benzer sonuçlara ulaşılmıştır. Libya Matematik ders kitaplarının görsel unsurlarının ve kağıt kalitesinin birbirleriyle uyumsuz olduğu hatta bir çok görselin açık zemin üzerinde yine açık renkte görselleştirildiği bununda öğrencinin okumasını, algılamasını zorlaştırabileceği öngörülmektedir. 
Ayrıca yapılan çalışmalarda ders kitaplarının öğrenci başarısında etkili olduğu bu nedenle çözümlü sorular ve açıklamaların daha iyi gerekçelendirilmesi ve daha fazla açıklama ile desteklenmesi gerektiği öneri sürülmektedir (Aineamani ve Naicker, 2014). Çalışmamızda da benzer sonuçlara ulaşılmıştır. Libya Matematik ders kitaplarında konu kavrama bölümündeki açıklamalar yeterli değildir. Kitaptaki soru sayısı yeterli olmakla birlikte çözümlü soru anlatımları yeterli değildir.

\subsection{Alıştırma Sorularının Nitelikleri, Zorluk Seviyeleri, Cevap Türleri ve Çözüm Süreçleri Açısından Değerlendirme}

Ders kitaplarının zorluk düzeyleri incelendiğinde tüme varım yöntemine uygun olarak kolaydan zora doğru hareket edildiği ve bu kapsamda soruların zorluk düzeyine ilişkin analiz sonuçlarına göre 7. Sınıf matematik ders kitabındaki alıştırmaların daha düşük zorluk düzeyine sahip iken 9. Sınıfta konu içeriklerinin zorlaştığı ortaya konulmuştur. Libya Matematik Ders Kitabında yer alan alıştırma sorularının çözümleri cevap türleri bakımından NAEP 2007 çerçevesinde "sayısal cevap", "sözel cevap", "cebirsel ifade" ve "tablo grafik şekil" içerip içermediği yönünde yapılan inceleme sonucunda 7. Sınıf matematik ders kitabında daha az tablo, şekil grafik vb unsurlar yer alırken cebirsel ifade ve sayısal cevabın yoğunlukta olduğu. 8. Sinıfta sayısal cevap ve cebirsel ifade yer alırken diğer sınıf düzeylerine göre de daha yüksek düzeyde olduğu ve 9. Sınıf matematik ders kitabında ise sayısal cevap, cebirsel ifade ve tablo, şekil grafik unsuru yoğun olarak bulunduğu ortaya konulmuştur. Sayısal cevap ve tablo, şekil ve grafik unsuru 9. Sınıfta diğer sınıflara göre yüksek düzeyde olduğu belirlenmiştir.

Alıştırma sorularının çözümünde tek işlem ve birden fazla (çok aşamalı işlem) olarak yapılan kodlamalardan elde edilen sonuçlara göre 7. ve 8. Sınıfta çok aşamalı işlem gereklerine sahip alıştırma soru sayısının çok olduğu 9. Sınıfta ise tek aşamalı işlem gereğine sahip alıştırma soru sayısının fazla olduğu 8 sınıfta çok aşamalı işlem gereklerine sahip soru sayısı diğer sınıf düzeylerine göre daha fazla olduğu sonucuna varılmıştır.

Genel bir değerlendirme yapılacak olursa sınıfta kullanılan ders kitabının, öğrencilerin matematiğe nasıl baktıklarını belirlemede çok önemli olduğu, ders kitabının, öğrencilerin matematik fikirlerini iletebilmelerini mümkün kılma veya kısıtlamalarına yardımcı olduğu ve ayrıca ders kitabı, soru sorarak, öğrencilere daha yüksek matematiksel akıl yürütmeleri için araştırma yapmasına rehberlik etmede önemlidir. Bu kapsamda alıştırma sorularında kullanılan görsellerin uyumlu olması öğrencilerin kavram öğrenmelerinde olumlu etki bıraktığı ve alıştırma sorularının öğrencilerin bireysel öğrenmelerine etki ettiği bilinmeli ve ders kitaplarının bu şekilde dizayn edilebilirliği göz önüne alınmalıdır.

Yapılan bu değerlendirme 2004 yılında Beckmann tarafından yapılan bir çalışmada Singapur'un TIMSS 1999 sonuçlarından elde ettiği başarılı sonucun ders kitaplarından kaynaklanabileceği ders kitaplarının anlatımında öğrencilerin daha iyi kavrayabilecekleri şekilde tasarlanabilmesinin gerektiği sonucuna vardığı çalışa ile uyumludur. Ayrıca Törnroos tarafından 2005 yılında yapılmıştır. Matematik ders kitabı içeriği ile TIMSS 1999 sorularını karşılaştırmış ve öğrencilerin başarısında ders kitaplarının ilişkisini ortaya koymayı amaçlamıştır. Bunun için Finlandiya 5, 6 ve 7. Sınıf matematik ders kitaplarını incelemiştir. Ders kitapları içeriklerinin doğru bir şekilde organize edildiğinde öğrenme firsatı yaratan en önemli gösterge olacağı sonucuna varılmıştır.

Yine Amerika Singapur ve Türkiye'de 8. Sinıfta okutulan Matematik Ders Kitaplarının analizini yapan Özer ve Sezer (2014) çalışma sonucunda Amerika Birleşik Devletleri, Singapur ve Türkiye'de okutulan ders kitaplarında sırasıyla çoklu işlem gerektiren kitapların yüzdesi sırasıyla $\% 90, \% 96$ ve $\% 85$ olarak bulunmuştur. Bu çalışma sonucunda ise \% 60,72 düzeyinde sayısal cevap, 32,48 düzeyinde zorluk düzeyi yüksek soru ve \%73,32 düzeyinde çoklu işlem 
gereklerine sahip soru bulunmuştur. Amerika, Singapur ve Türkiye'deki matematik ders kitaplarına göre düşük bir oran elde edilmiştir (Özer ve Sezer, 2014).

\section{4. Öneriler}

$\mathrm{Bu}$ çalışma sonuçları temelinde, kitap yazarlarına, yayınevlerine, kitap inceleme ve değerlendirme komisyonlarına, kitap inceleme ve karşılaştırma çalışmaları yapacak araştırmacılara aşağıdaki öneriler sunulabilir.

- Ders kitaplarına öğrencilerin bilgilerini uygulayabilmelerini sağlayıcı daha fazla sayı ve çeşitte soru eklenmesi yararlı olabilir. Libya Eğitim Bakanlığı bünyesinde hazırlanan ders kitapları için yardımcı bir kitap bulunmamaktadır. Bu kapsamda öğrenci çalışma kitapları hazırlanabilir.

- Yine ders kitapları için öğretmen kılavuz kitapları hazırlanarak her sınıf seviyesinde tüm öğrencilere aynı bilgilerin verilmesi böylece olumsuz farklılıkların ortadan kaldırılması sağlanabilir.

- Çözümlü örneklerin sayısı artırılabilir ve örnekler güncel yaşam problemleri içerebilir.

- Ders kitaplarında yer alan görsel unsurların kavram karmaşasına sebep olmayacak şekilde yeniden düzenlenmesi sağlanabilir.

- Çözümlü sorularda alternatif çözüm yöntemlerine yer verilebilir.

- Alıştırma soruları farklı bilişsel düzeylere hitap etmeli kolaydan zora doğru bir sistematikle ilerlemelidir.

- Konuların doğru anlaşılabilmesi için muhakeme ve ispata yönelik sorulara ve çözümlerine yer verilebilir

- Kavram karikatürlerine yer verilmeli bunlar oluşturulurken matematiksel bilgilerin kavranmasını kolaylaştırıcı etkisi olan görsellerden yararlanılmalıdır.

- Kitaplarda sadelik ön planda olmalı ve tüm ünite ve alt konu başlıkları aynı stil ve tasarımla oluşturulmalı gereksiz ve detay görsel kullanımına dikkat edilmelidir.

- Ders kitabına yardımcı materyaller ilgili sınıf seviyesinde web sayfasında listenebilir olmalıdır. Böylece bireysel öğrenmelerde katkı sağlanabilir.

- Alıştırma soruları önceden uygulanmış cevapları belli olan sorular olmalı cevapları olmayan ya da testlerde yanlış şıkları olan sorulara ders kitabında yer verilmemesine dikkat edilmelidir.

- Ders kitapları ve ders programları incelemeleri Libya Eğitim Bakanlığı tarafından desteklenmeli ve tez çıktıları Bakanlık tarafından incelenmelidir. Böylece politika yapıcıların yeniden değerlendirmeleri sonucunda programlar ve ders kitapları iyileştirilebilir.

\section{KAYNAKÇA}

Aineamani, B. (2010). Reasoning and communicating mathematically. In M. de villers (Ed.), Proceedings of 18th meeting of SAARMSTE Vol 1, University of Kwazulu-Natal: South Africa, pp. 171-183.

Aineamani, B. \& Naicker, S. (2014). Mathematics text book analysis: A guide to choosing the appropriate mathematics textbook. The Association for Mathematics Education of SouthAfrica-AMESA.

Dane, A., Doğar, Ç. \& Balkı, N. (2004). İlköğretim 7. sınıf matematik ders kitaplarının değerlendirmesi. Erzincan Ĕgitim Fakültesi Dergisi, 6(2), 1-18. 
Dowling, P. (1996). A Sociological analysis of school mathematics texts. Educational Studies in Mathematics, 31(4), 389-485

Duman, T., Karakaya, N., Çakmak, M., Eray, M. \& Özkan, M. (2001). Konu alanı ders kitabr incelemesi. L. Küçükahmet (Editör), s.10-40. Ankara: Nobel Yayın Dağıtım.

Göze, N. (1999). Matematik zor değildir. Çağdaş Eğitim Dergisi, 256, 33-37.

Kilpatrick, J., Swafford, J. \& Findell, B. (Eds). (2001). Adding it up: helping children learn mathematics. Washington: National Academy Press. Pp. 115-155.

Kolaç, E. (2003). İlköğretim dördüncü sınıf Türkçe ders kitaplarının öğretmen görüşlerine dayalı olarak değerlendirilmesi. Uludă̆ Üniversitesi Ĕ̆itim Fakültesi Dergisi, 17(1), 105-137.

Marton, F., Runesson, U. \& Tsui, B.M. (2004). The space of learning. In F. Marton \& A. B. Tsui (Eds.), Classroom discourse and the space of learning (pp. 3 - 40), Mahwah, NJ: Lawrence Erlbaum.

McKenzie, F. (2001). Developing children's communication skills to aid mathematical understanding, ACE papers (Student Edition), 11, 7-16. https://researchspace.auckland.ac.nz/bitstream/handle/2292/25104/ACE_Paper_1_Issue _11.pdf?sequence=1

Morgan, C., (2004), Writing mathematically: the discourse of investigation, London: Falmer Press

Mukucha, J. (2012). The mathematics definition discourse: teachers' practices in multilingual classrooms (Doctoral dissertation) M. Sc. University of the Witwatersrand, Faculty of Science, School of Science Education, Johannesburg, Güney Afrika. Cumhuriyeti

Muller, M. \& Maher, C. (2009). Learning to reason in an informal math after-school program. Mathematics Education Research Journal, 21 (3), 109-119.

NAEP (2007) National assessment of educational progress at grades 4 and 8 https://nces.ed.gov/nationsreportcard/pdf/main2007/2007494.pdf

Ozer, E. \& Sezer, R. (2014). A comparative analysis of questions in American, Singaporean, and Turkish mathematics textbooks based on the topics covered in $8^{\text {th }}$ grade in Turkey. Educational Sciences: Theory and Practice, 14(1), 411-421.

Sadoski, M. (2001). Resolving the effects of concreteness on 1nterest, comprehension, and learning important ideas from text. Educational Psychology Review, 13 (3), 263-281.

Şirin, O. \& İncikabı, L. (2019). Süreli çocuk yayınlarındaki matematik problemlerinin incelenmesi. Eğitimde Kuram ve Uygulama, 15(3), 186-203.

Vygotsky, L. (1978). Mind in society: The development of higher psychological processes. Cambridge, MA: Harvard University Press.

Yıldırım, A. \& Şimşek, H. (2011). Sosyal bilimlerde araştırma yöntemleri. Ankara: Seçkin Yayınları.

Zhu, Y. \& Fan, L. (2006). Focus on the representation of problem types in intended curriculum: A comparison of selected mathematics textbooks from Mainland China and the United States. International Journal of Science and Mathematics Education, 4(4), 609-626. 